\title{
Effects of Exercise in Children and Adolescent with Type 1 Diabetes Mellitus
}

\author{
Lorenzo Iughetti*, Sara Gavioli, Annalisa Bonetti, Barbara Predieri \\ Department of Medical and Surgical Sciences of Mothers, Children and Adults, University of Modena and \\ Reggio Emilia, Modena, Italy \\ Email: iughetti.lorenzo@unimore.it
}

Received 24 August 2015; accepted 26 October 2015; published 29 October 2015

Copyright $@ 2015$ by authors and Scientific Research Publishing Inc.

This work is licensed under the Creative Commons Attribution International License (CC BY). http://creativecommons.org/licenses/by/4.0/

(c) ()

\begin{abstract}
Exercise is one of the most important components, together with insulin therapy and diet, in the clinical management of type 1 diabetes mellitus (T1DM). Physical activity has multiple health benefits, like blood pressure reduction, improvement of cardiovascular fitness and lipoprotein profile. The benefits for children with diabetes may also include positive effects on glycemic metabolism. The following review examines the main studies about the effects of exercise on diabetes. Additional longitudinal studies are needed to verify the hypothetical positive relationship between sport and T1DM and between sport and diabetic complications. However, aerobic and moderate intensity physical activity in children and adolescents with T1DM should be encouraged also for its beneficial psychological effects.
\end{abstract}

\section{Keywords}

Type 1 Diabetes Mellitus, Exercise, Hypoglycemia, Hyperglycemia

\section{Introduction}

Physical exercise is characterized by different hormonal and metabolic changes (Figure 1) [1] [2].

During physical activity, muscles involved in exercise receive an increased blood flow that improves oxygen and energy substrates delivery and removes carbon dioxide.

The increased muscle energy requirements cause a reduction of blood glucose concentration, which leads to the suppression of insulin secretion and activation of counter-regulatory responses [3]. At the level of muscular cells, these energetic requests are sustained by increased intracellular adenosine triphosphate concentration, followed by the activation of glycolisis and glycogenolysis.

${ }^{*}$ Corresponding author. 


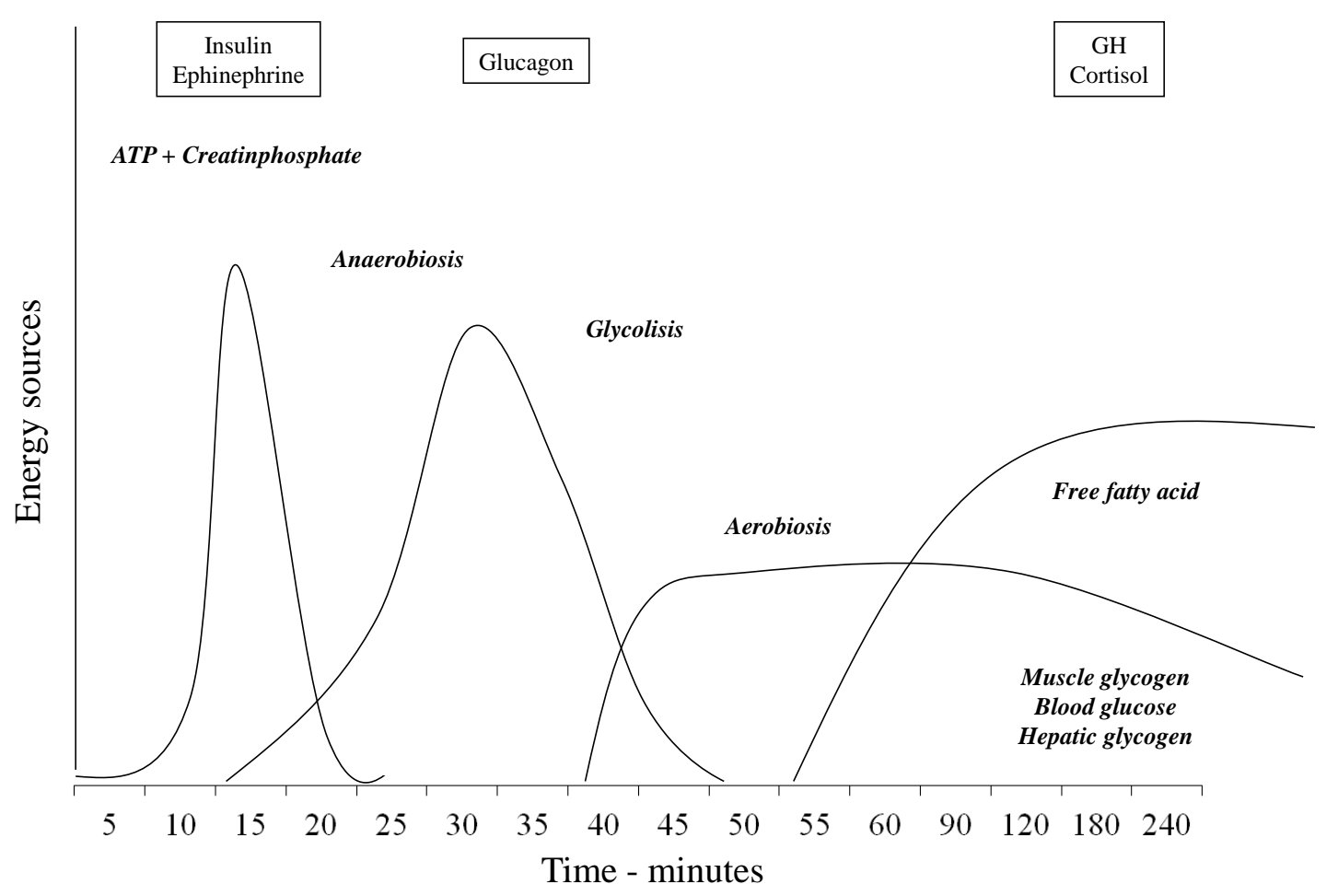

Figure 1. Metabolic and hormonal changes during exercise.

Therefore, the hormonal changes that characterize this early phase are the reduction of absolute concentration of insulin, increased levels of circulating epinephrine and muscular insulin concentration, due to the higher local blood flow.

The activation of hepatic glycogenolisis, gluconeogenesis, and adipose lypolisis protect against hypoglycemia and, at the same time, guarantee a continuous amount of glucose to the muscles in order to replace the molecules removed by the metabolic consumption. This second step is characterized by increased secretion of cortisol and growth hormone [1] [2] [4].

This is how circulating glucose levels are kept within the normal ranges, even when exercise lasts for hours.

The activation of the different metabolic processes depends on several factors, such as duration, type and intensity of exercise, physical training and diet [5]-[9].

The duration of the exercise, as mentioned above, causes the gradual transition from the oxidation of glucose to the fatty acid oxidation [6].

The type of exercise performed is of importance, as it changes the way of generating energy in the muscles. Anaerobic activities are characterized by higher intensities and shorter muscular contractions and are sustained by the glycolytic system. These activities tend to cause dramatic increases in blood glucose levels.

Aerobic activities are characterized by lower intensities of muscular contraction. These contractions are usually more prolonged and their substrates are carbohydrates, fats, and some proteins for mitochondrial oxidation. Aerobic metabolism is the primary method of energy production during endurance activities and causes blood glucose decrease both during and post activity.

Intensity of exercise, expressed by maximal oxygen uptake $\left(\mathrm{VO}_{2} \mathrm{max}\right)$, plays as well a role in the energetic metabolism. Carbohydrates are the main source in case of high intensity exercise. On the contrary, in situations of long-lasting physical activity of low intensity, fats oxidation increases [7].

Another cofactor affecting the energetic metabolism is the physical training: it improves the capability of employ fat for energy, the insulin sensitivity and the activity of the skeletal muscle glycogen synthesis [8].

Finally, a diet rich in carbohydrates can increase carbohydrates oxidation during exercise. Furthermore, carbohydrates intake may also restore hepatic and muscular glycogen, leading to adequate glucose production during the exercise [9]. 


\section{Short-Term Effects of Physical Activity on T1DM Children}

In children with T1DM, the insulin levels during exercise are independent by the counter-regulatory processes, as peripheral insulin concentration depends on injected amount and pharmacological formulation, and the time elapsed since the last administration [10] [11]. Therefore differently from healthy children, the regulation of blood glucose concentration during exercise is not well controlled: the physiological suppression of insulin is totally absent.

The result is an inadequate or exaggerated activity of the muscular uptake of glucose, the liver production of glucose, and the free fatty acids production in the adipose tissue. Because of the blunted metabolic changes, exercise in patients with T1DM may induce hypoglycaemic or hyperglycemic episodes (Figure 2 and Figure 3), both during or several hours after physical activity.

\subsection{Hypoglycemia}

Hypoglycemia is the most frequent adverse event during or after muscle activation in patients with T1DM. Several circumstances may induce an increased blood concentration of insulin, which results in hypoglycemia:

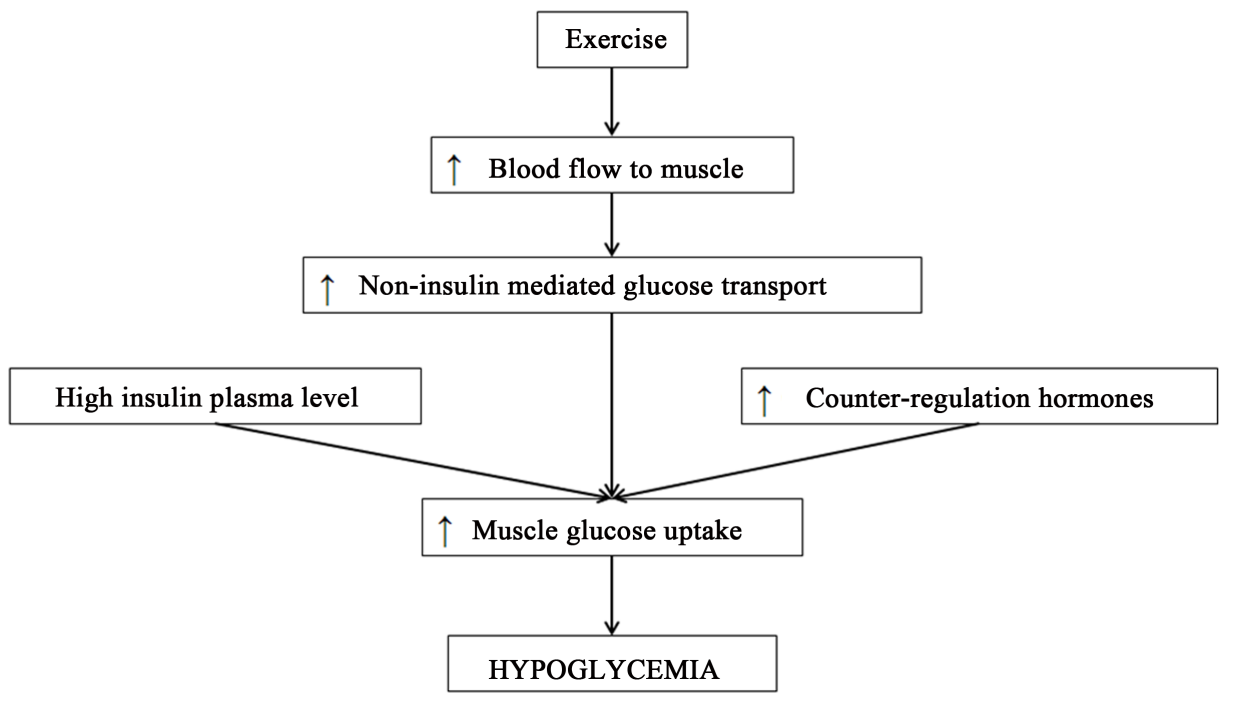

Figure 2. Response to exercise in the diabetic subject with hyperinsulinization.

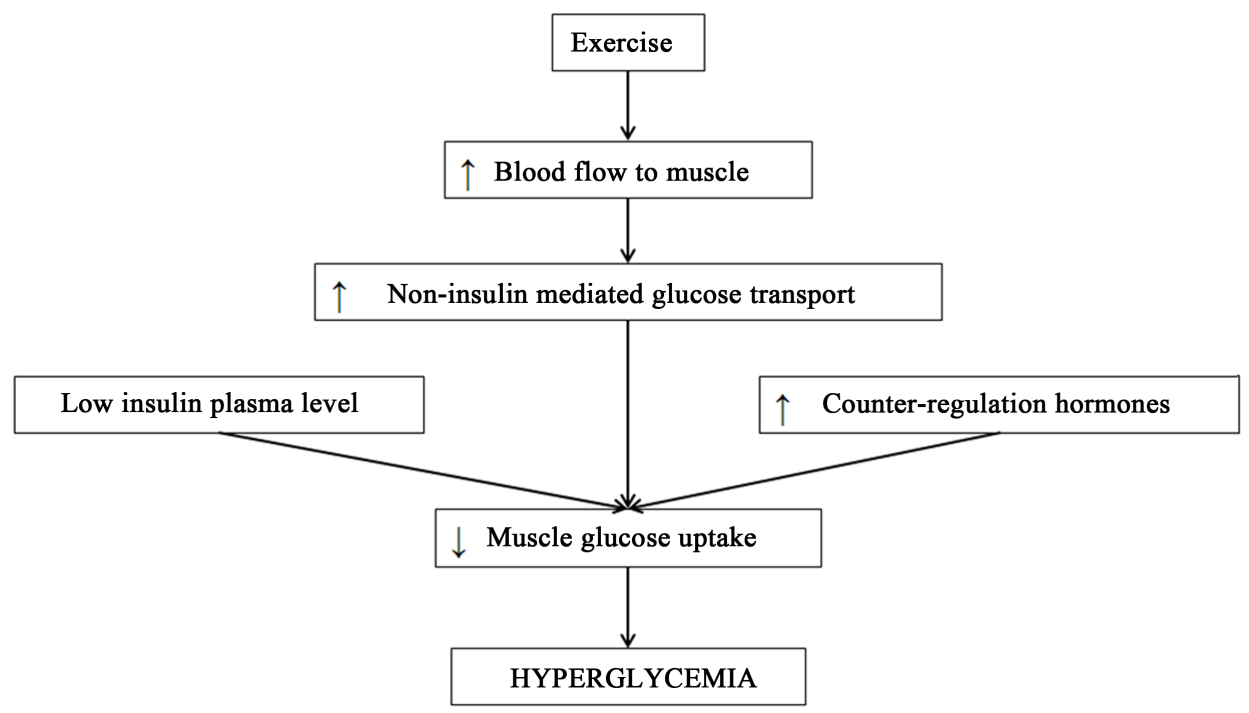

Figure 3. Response to exercise in the diabetic subject with hypoinsulinization. 
-Serum insulin concentration is independent by exercise because insulin is given by injection or pump [10] [11].

-Serum insulin concentration may be increased by exercise if the injection is performed in a muscle involved in the physical activity [11].

-Insulin-suppression, mediated by the adrenergic system, is absent at the beginning of the muscular work [12].

-Exercise induces an increased insulin sensitivity that may induce an exaggerated glucose uptake. This effect appears to be enhanced by hyperinsulinemic levels, especially after exercise. As the insulin sensitivity increases during and after exercise, the glycogen stores decrease, the muscle glucose uptake increases, and hypoglycemia may occurs later, mainly during the night [13].

-Blunted insulin/glucagon rate and inadequate hepatic glucose production [14].

-The decreased sympathetic nervous system activity causes an impaired counter-regulatory response.

These alterations result in a reduction of counter-regulatory responses exercise-related and cause the fall in glucose levels [15].

All these factors increase the risk of exercise-induced hypoglycemia in diabetic patients. A number of factors may affect the neurohormonal changes during exercise, increasing the risk of hypoglycemia: glycemic trend, antecedent hypoglycemic episodes, timing of exercise along with the last insulin injection, higher absorption of peripherally injected insulin, duration and type of activity, increased insulin sensitivity after exercise, timing and type of pre-exercise diet, autonomic defects [16] [17]. The glycemic trend before, during and after exercise, and especially antecedent hypoglycemic episodes play a central role in the control of glycemia, In fact, an antecedent hypoglycemic episode compromise the neurohormonal changes, inducing an increased risk of hypoglycemia during the muscle activation [16]. The interval between the last insulin injection and the beginning of exercise represents another important factor responsible for hypoglycemia: the risk is higher with the shorter the interval. This effect may be amplified by insulin injection into working muscle [18].

\subsection{Hyperglycemia}

Physical exercise in diabetic patients may cause an increased risk of both hyperglycemia and ketosis. Adequate insulin concentrations regulate blood glucose levels and prevent hyperglycemia. Furthermore, insulin makes possible local glucose uptake in the working muscles and may balance an excessive blood glucose increase, due to counter-regulatory hormones. Low insulinemia at the beginning of the physical activity may cause severe hyperglycemia and ketoacidosis [19]. As muscular activity begins, hyperglycemia and ketoacidosis will deteriorate, with a further increase in the production of counter-regulatory hormones [20]. Hyperglycemia and ketosis are strongly influenced by the interval between the last insulin injection and the exercise, especially if exercise begins too late in comparison to the injection, as the insulinemia decreases progressively after injection. All these effects may be worsened if high glycemic levels occur before exercise.

Prolonged and high intensity exercise may increase the risk of hyperglycemia and muscle metabolism is predominantly based on lipid oxidation [21]. High intensity exercise causes an increase in glucose production through the activation of the counter-regulatory responses [22].

\section{Long-Term Effects of Physical Activity on T1DM Children}

It is generally known that physical activity has multiple health benefits. In T1DM children with adequate metabolic control, regular physical exercise improves insulin sensitivity, resulting in a reduction in the insulin daily needs [23]. Furthermore regular activity is associated with reduction of glycemic levels during and after exercise and lower post-prandial glycemic peak [24].

Several studies support the hypothesis that physical activity improves metabolic control in T1DM children [25]-[38] (Table 1). Huttunen et al. studied a sample of 84 T1DM children compared with 94 healthy controls. They found that physical working capacity was inversely related to concentration of HbA1c in diabetic boys [25]. The same group studied 32 youth with T1DM: half of them participated to a training program and the others were involved in non-physical activities for the same period of time (1 hour/week for 3 month). Any group showed an improved metabolic control; nevertheless, when the study group was stratified for level of participation, metabolic control was significantly better in the patients that participated regularly, regardless of the type of activity [27]. Herbst et al., in a sample of 19.143 patients, demonstrated that frequency of regular physical activity represents an important factor for the glycosilated haemoglobin level (HbA1c), with no increasing risk of 
Table 1. Main studies on effects of exercise in children with T1DM. Abbreviations: T1DM, type 1 diabetes mellitus; yrs., years; HbA1c, glycosilated haemoglobin; PWC, Physical Working Capacity; wk, week; mo., month; RPA, regular physical activity; $\mathrm{BMI}$, body mass index; $\mathrm{VO}_{2}$ max, maximal oxygen uptake; $\mathrm{CHO}$, carbohydrate.

\begin{tabular}{|c|c|c|c|c|}
\hline Author & Patient & Method & $\begin{array}{l}\text { Main Outcome } \\
\text { Measures }\end{array}$ & Results \\
\hline $\begin{array}{l}\text { Huttunen } \\
\text { et al. [25] }\end{array}$ & $\begin{array}{c}84 \text { T1DM (6.3 - } 18.8 \text { yrs.) } \\
94 \text { healthy controls } \\
(8.5-18.8 \text { yrs. })\end{array}$ & $\begin{array}{c}\text { Submaximal progressive } \\
\text { exercise test }\end{array}$ & HbA1c & $\begin{array}{l}\text { PWC is lower in T1DM boys } \\
\text { PWC is inversely related } \\
\text { to age }(p<0.01) \text { and } \\
\text { HbA1c }(p \leq 0.025)\end{array}$ \\
\hline $\begin{array}{l}\text { Ludvigsson } \\
\text { et al. [26] }\end{array}$ & $\begin{array}{c}143 \text { T1DM } \\
(1-16 \text { yrs.; } 7.3 \pm 3.9 \text { yrs. })\end{array}$ & $\begin{array}{l}\text { Weekly history of } \\
\text { physical activity }\end{array}$ & Glycosuria & $\begin{array}{c}\text { Positive correlation } \\
\text { between degree of } \\
\text { exercise and metabolic } \\
\text { control }(\mathrm{r}=0.54, p<0.001)\end{array}$ \\
\hline $\begin{array}{l}\text { Huttunen } \\
\text { et al. [27] }\end{array}$ & $\begin{array}{c}32 \text { T1DM } \\
\text { (8.2 - } 16.9 \text { yrs.; } 11.9 \text { yrs.) }\end{array}$ & $\begin{array}{c}\text { Exercise group }(\mathrm{n}=16) \text {, } \\
1 \text { h/wk of training for } 3 \text { mo. } \\
\text { Non exercise group }(\mathrm{n}=16) \text {, } \\
1 \text { h/wk of non-physical } \\
\text { activity for } 3 \text { mo. }\end{array}$ & HbA1c & $\begin{array}{l}\text { HbA1c was significantly } \\
\text { better among T1DM subjects } \\
\text { participating frequently } \\
\text { ( } \geq 11 \text { - } 13 \text { sessions) than } \\
\text { among those participating } \\
\text { infrequently ( }<11 \text {-13 sessions) }\end{array}$ \\
\hline $\begin{array}{l}\text { Sackey } \\
\text { et al. [28] }\end{array}$ & 135 T1DM children & $\begin{array}{l}\text { Home diary for } 6 \text { days } \\
\text { period to record details } \\
\text { of physical activity }\end{array}$ & $\begin{array}{l}\text { Fructosamine } \\
\text { Blood glucose } \\
\text { Subscapular } \\
\text { skin fold thickness }\end{array}$ & $\begin{array}{l}\text { Negative correlation between } \\
\text { early morning activity } \\
\text { and blood glucose }(p=0.004)\end{array}$ \\
\hline $\begin{array}{l}\text { Herbst } \\
\text { et al. [29] }\end{array}$ & $\begin{array}{l}\text { 19.143 T1DM } \\
(3-20 \text { yrs.) }\end{array}$ & Recording frequency of RPA & $\begin{array}{c}\text { HbA1c } \\
\text { BMI } \\
\text { Hypoglycemia }\end{array}$ & $\begin{array}{c}\text { HbA1c is lower in groups } \\
\text { with more frequent RPA } \\
\text { In female BMI is lower in groups } \\
\text { with more } \\
\text { frequent RPA No influence } \\
\text { of RPA on hypoglycaemia }\end{array}$ \\
\hline $\begin{array}{c}\text { Dahl-Jorgensen } \\
\text { et al. [30] }\end{array}$ & 22 T1DM (11 yrs.) & $\begin{array}{l}\text { Exercise group }(\mathrm{n}=14) \text {, } \\
1 \text { h/twice weekly of supervised } \\
\text { exercise program for } 5 \text { mo. } \\
\text { Non exercise group }(\mathrm{n}=8)\end{array}$ & $\begin{array}{c}\text { HbA1c } \\
\text { Blood Glucose } \\
\text { Glycosuria } \\
\text { Insulin-dosage } \\
\text { per kilo body weight }\end{array}$ & $\begin{array}{l}\text { No change in blood glucose, } \\
\text { insulin dosage and } \\
\text { glycosuria Reduction of } \\
\text { HbA1c from } 15.1 \pm 2.2 \\
\text { to } 13.8 \pm 1.9(p<0.001)\end{array}$ \\
\hline $\begin{array}{l}\text { Stratton } \\
\text { et al. }[31]\end{array}$ & 16 T1DM adolescents & $\begin{array}{l}\text { Supervised exercise group }(\mathrm{n}=8) \text {, } \\
8 \text { wk program of supervised } \\
\text { exercise Non supervised exercise } \\
\text { group }(\mathrm{n}=8), 8 \text { wk program } \\
\text { of non supervised exercise }\end{array}$ & $\begin{array}{l}\text { Glycosylated } \\
\text { serum albumin } \\
\text { Blood glucose }\end{array}$ & $\begin{array}{c}\text { Improvement of } \\
\text { glycosylated serum albumin } \\
\text { and of blood glucose values } \\
\text { in the supervised } \\
\text { exercise group }\end{array}$ \\
\hline $\begin{array}{l}\text { Campaigne } \\
\text { et al. [32] }\end{array}$ & 19 T1DM (5 - 11 yrs.) & $\begin{array}{c}\text { Exercise group }(\mathrm{n}=9), \\
30 \text { minutes of vigorous exercise, } \\
3 \text { times/wk for } 12 \text { wks } \\
\text { Non exercise group }(\mathrm{n}=10)\end{array}$ & $\begin{array}{l}\text { HbA1c } \\
\text { Blood glucose }\end{array}$ & $\begin{array}{l}\text { Decrease of HbA1c } \\
\text { and blood glucose } \\
\text { in the exercise group }\end{array}$ \\
\hline $\begin{array}{c}\text { Mauvais-Jarvis } \\
\text { et al. }[33]\end{array}$ & $\begin{array}{l}12 \text { T1DM adults } \\
\text { (32 } \pm 7 \text { yrs.) }\end{array}$ & $\begin{array}{l}\text { 1. Occasion, 60-min high-intensity } \\
\text { cycle exercise performed with the } \\
\text { usual morning insulin dose } \\
\text { 2. Occasion, } 60 \text {-min high-intensity } \\
\text { cycle exercise performed after } \\
50 \% \text { - } 90 \% \text { reduction of } \\
\text { morning insulin dose }\end{array}$ & Blood glucose & $\begin{array}{l}\text { T1DM patients can perform in- } \\
\text { tense muscle exercise } \\
\text { after a } 50 \% \text { - } 90 \% \text { without } \\
\text { worsening metabolic control }\end{array}$ \\
\hline $\begin{array}{l}\text { Mosher } \\
\text { et al. [34] }\end{array}$ & $\begin{array}{c}10 \text { T1DM }(17.2 \pm 1.2 \text { yrs. }) \\
10 \text { healthy controls } \\
(19.4 \pm 1.3 \text { yrs. })\end{array}$ & $\begin{array}{l}\text { Mixed endurance and } \\
\text { calisthenic/strength } \\
\text { Activities performed at a rapid } \\
\text { pace three times weekly } \\
\text { for } 12 \mathrm{wks}\end{array}$ & $\begin{array}{c}\text { Blood glucose } \\
\text { HbA1c } \\
\text { Lean/Fat body mass }\end{array}$ & $\begin{array}{l}\text { Increase in lean body mass } \\
\text { Reduction in body fat } \\
\text { No change in blood glucose } \\
\text { Reduction of } 0.96 \% \text { in HbA1c }\end{array}$ \\
\hline $\begin{array}{l}\text { Larsson } \\
\text { et al. [35] }\end{array}$ & $\begin{array}{l}6 \text { T1DM }(15-19 \text { yrs. }) \\
6 \text { healthy controls } \\
(15-19 \text { yrs. })\end{array}$ & $\begin{array}{c}\text { Training program consisting } \\
\text { in } 5 \text { months’ regular } \\
\text { physical activity }\end{array}$ & $\begin{array}{l}\mathrm{VO}_{2} \text { max } \\
\text { Heart volume } \\
\text { Glycosuria } \\
\text { CHO intake }\end{array}$ & $\begin{array}{c}\text { Similar and significant } \\
\text { increase in } \mathrm{VO}_{2} \text { max and } \\
\text { heart volume in both groups } \\
\text { Unchanged glycosuria after in- } \\
\text { crease of CHO intake }\end{array}$ \\
\hline
\end{tabular}




\begin{tabular}{|c|c|c|c|c|}
\hline \multicolumn{5}{|l|}{ Continued } \\
\hline $\begin{array}{l}\text { Landt } \\
\text { et al. }[36]\end{array}$ & 15 T1DM adolescent & $\begin{array}{c}\text { Exercise group }(\mathrm{n}=9), 45 \\
\text { minutes for } 3 \text { times/wk for } 12 \mathrm{wks} \\
\text { Non exercise group }(\mathrm{n}=6)\end{array}$ & $\begin{array}{c}\text { Insulin sensitivity } \\
\text { HbA1c }\end{array}$ & $\begin{array}{l}\text { Increase in insulin } \\
\text { sensitivity }(23 \% \pm 5 \%) \\
\text { Unchanged HbA1c }\end{array}$ \\
\hline $\begin{array}{l}\text { Roberts } \\
\text { et al. [37] }\end{array}$ & Adolescent with T1DM & $\begin{array}{l}12 \text { wks of supervised } \\
\text { training followed by } 12 \text { wks } \\
\text { unsupervised training }\end{array}$ & $\begin{array}{c}\text { Aerobic capacity } \\
\text { HbA1c }\end{array}$ & $\begin{array}{l}\text { Improve of aerobic capacity } \\
\text { during supervised training } \\
\text { HbA1c not affected by training }\end{array}$ \\
\hline $\begin{array}{l}\text { Zinman } \\
\text { et al. [38] }\end{array}$ & $\begin{array}{l}15 \text { T1DM youth } \\
7 \text { healthy subjects }\end{array}$ & $\begin{array}{l}45 \text { minutes of cycle } \\
\text { exercise } 3 \text { times/wk } \\
\text { for } 12 \mathrm{wks}\end{array}$ & $\begin{array}{c}\text { Blood glucose } \\
\text { HbA1c } \\
\mathrm{VO}_{2} \text { max } \\
\text { Body weight } \\
\text { Caloric intake }\end{array}$ & $\begin{array}{l}\text { Increase of caloric intake } \\
\text { on exercising days } \\
\text { Unchanged HbA1c }\end{array}$ \\
\hline
\end{tabular}

severe hypoglycemia [29]. These findings suggest a relationship between increased aerobic capacity and improved glycemic control. In addition, glycemic control appears to be improved among diabetic patients motivated to participate to any kind of activity.

However, few are the longitudinal studies at the moment, and their findings are controversial.

Some clinical trials documented beneficial effects of exercise on glycemic control [30]-[34]. Stratton R et al., studying a sample of 16 diabetic patients, found that after an exercise-program of 8 weeks, glycosilated serum albumin and blood glucose values improved despite reduced daily insulin dosage [31]. Mauvais-Jarvis F et al. demonstrated that T1DM patients could perform intense muscle exercise after a 50\% - 90\% reduction in insulin dose. The decrease prevents hypoglycemia without worsening the metabolic control [33]. In an intervention trial with control group, Mosher PE et al. showed a significant reduction of HbA1c (0.9\%) after 12 weeks of exercise-program [34].

On the other side, many studies showed no improvement in glycemic control after physical activity [35] [36]. Landt KW et al. found that, after a program of exercise training lasted for 12 weeks, insulin sensitivity improved despite HbA1c levels remained constant $(12 \% \pm 1 \%)$, indicating that exercise training alone does not improve glycemic control [36].

Roberts L et al. demonstrated that the average levels of HbA1c both in poorly and well-controlled diabetic patients were not affected by exercise (12 weeks of supervised training followed by 12 weeks of unsupervised training). These findings indicate that, irrespective of glycemia prior to the exercise training, glycemic control does not improve in response to exercise training alone [37].

Improvements in $\mathrm{VO}_{2}$ max without changes in glycemic control have been reported by Zinman et al. after 12 weeks of bicycle and treadmill exercise respectively [38].

The controversial results of the reported studies might be due to the different methodological approaches and, in some cases, to the small number of patients. In addition, a further explanation could be given by the excessive intake of carbohydrates to prevent hypoglycemia. This caloric intake can neutralize the beneficial glycemic lowering effects of physical activity. However, as it is well known, exercise together with insulin therapy and diet, is one of the three most important factors affecting the long-term metabolic control. Its role could be explained by various beneficial effects, commonly observed also in the healthy population. Physical activity in children and adolescents affected by T1DM should be encouraged regardless of its hypothetical beneficial effects on glucose metabolism, mainly its positive effects on cardiovascular risk, i.e. improvement of lipoprotein profile and cardiovascular fitness, and decreased blood pressure [39] [40].

A multicenter study conducted on 23.251 patients confirms that increasing physical activity in children with T1DM is associated with a beneficial cardiovascular risk profile, such as lower lipoprotein levels and decreased diastolic blood pressure, associated with better glycemic control [41].

These effects are particularly important in diabetic children at high risk of atherosclerotic complications. Patients with T1DM have a 4-fold (men) to 8-fold (women) increased risk of coronary heart disease compared with the general population [42]. Long-standing diabetes, age, poor glycemic control, smoking, hypertension, obesity and dyslipidemia are the principal causes of this additional risk.

Beneficial effects on psychological well-being, cardiovascular fitness, muscle capacity and especially on obesity may be reported even for this group of patients. Mosher PE et al. found that after physical activities performed regularly (3 times/week for 12 weeks), diabetic adolescents increased their lean body mass and improved their cardiorespiratory endurance and their strength [34]. 
From the considerations made so far, it appears that regular physical activity may prevent complications of diabetes. However, exercise may worsen the diabetes-related chronic complications. Patients that have proliferative retinopathy or nephropathy should avoid exercise conditions that can result in high arterial blood pressures. [43]. In fact, high-intensity exercise may cause progression of microvascular damage, leading to vitreal haemorrhage or retinal detachment in patients with diabetic retinopathy, and increase of proteinuria in those with diabetic nephropathy [44] [45].

Diabetic neuropathy affects the autonomic nervous system, involved in all involuntary function. Several effects may be due to this condition: decreased maximal cardiac capacity and outputs, decreased cardiovascular rate during exercise, orthostatic hypotension, impaired sweating, impaired gastrointestinal function [46]-[49].

The relationship between physical activity and prevention/progression of diabetes complications has been poorly studied. The Epidemiology of Diabetes Complications Study in 1991 found an inverse relationship between physical activity and presence of complications. History of physical activity of each patient was examined as well, showing the same inverse relationship [50].

Recently, a cross-sectional study on 1.945 patients about leisure time physical activities (LTPA), showed a lower frequency of LTPA in patients with microalbuminuria than in those with a normal renal function. These results suggested the hypothesis that a reduced frequency of physical activity precedes the onset of complications because microalbuminuria alone can’t be a limitation to exercise [51].

\section{Conclusion}

Exercise together with insulin therapy and diet, is generally recognized as one of the most important tools in the clinical management of youth with diabetes. However, the studies performed reached controversy results. Our review of the literature suggests that longitudinal studies are needed in order to verify the hypothetical positive effect of exercise on glucidic metabolism and on prevention and progression of complications in diabetic patients. On the other hand, practical guidelines are necessary to limit the risks of exercise-related hypoglycemia or hyperglycemia. Furthermore, each patient should know their individual glycemic response to exercise in order to correctly modify insulin dosage and diet. However, aerobic and moderate intensity physical activity in children and adolescents with T1DM should be encouraged for its beneficial psychological effects.

\section{References}

[1] Marliss, E.B. and Vranic, M. (2002) Intense Exercise Has Unique Effects on Both Insulin Release and Its Roles in Glucoregulation. Diabetes, 51, S271-S283. http://dx.doi.org/10.2337/diabetes.51.2007.S271

[2] Kreisman, S., Mew, N., Arsenault, M., et al. (2000) Epinephrine Infusion during Moderate Intensity Exercise Increases Glucose Production and Uptake. American Journal of Physiology, 278, E949-E957.

[3] Bradley, Z., Allison, R., Lacy, B. and Wasserman, D. (1997) Interaction of Exercise, Insulin, and Hypoglycemia Studied Using Euglycemic and Hypoglycemic Insulin Clamps. American Journal of Physiology, 272, E530-E542.

[4] Thorell, A., Hirshman, M.F., Nygren, J., et al. (1999) Exercise and Insulin Cause GLUT-4 Translocation in Human Skeletal Muscle. American Journal of Physiology, 277, E733-E741.

[5] Marliss, E., Simantirakis, E., Gougeon, P., Halter, C. and Vranic, M. (1991) Glucoregulatory and Hormonal Responses to Repeated Bouts of Intense Exercise in Normal Male Subjects. Journal of Applied Physiology, 71, 924-933.

[6] Romijn, J.A., Coyle, E.F., Sidossis, L.S., et al. (1993) Regulation of Endogenous Fat and Carbohydrate Metabolism in Relation to Exercise Intensity and Duration. American Journal of Physiology, 265, E380-E391.

[7] Romijn, J.A., Coyle, E.F., Sidossis, L.S., Rosenblatt, J. and Wolfe, R.R. (2000) Substrate Metabolism during Different exercise Intensities in Endurance-Trained Women. Journal of Applied Physiology, 88, 1707-1714.

[8] De Feo, P., Di Loreto, C., Lucidi, P., et al. (2003) Metabolic Response to Exercise. Journal of Endocrinological Investigation, 26, 851-854. http://dx.doi.org/10.1007/BF03345235

[9] Jeukendrup, A., Wagenmakers, A., Stegen, J., Gijsen, A., Brouns, F. and Saris, W. (1999) Carbohydrate Ingestion Can Completely Suppress Endogenous Glucose Production during Exercise. American Journal of Physiology, 276, E672E683.

[10] Wasserman, D.H. and Zinman, B. (1995) Fuel Homeostasis in “The Health Professional's Guide to Diabetes and Exercise”. ADA Clinical Education Series, 29-47.

[11] Frid, A., Ostman, J. and Linde, B. (1990) Hypoglycaemia Risk during Exercise after Intramuscular Injection of Insulin in the Thigh of IDDM. Diabetes Care, 8, 337-343. 
[12] Robertson, R.P., Halter, J.B. and Porte Jr., D. (1976) A Role for Alpha-Adrenergic Receptors in Abnormal Insulin Secretion in Diabetes Mellitus. Journal of Clinical Investigation, 57, 791-795. http://dx.doi.org/10.1172/JCI108338

[13] MacDonald, M.J. (1987) Postexercise Late-Onset Hypoglycemia in Insulin-Dependent Diabetic Patients. Diabetes Care, 10, 584-588. http://dx.doi.org/10.2337/diacare.10.5.584

[14] Zinman, B., Murray, F.T., Vranic, M., Albisser, A.M., Leibel, B.S., Mcclean, P.A. and Marliss, E.B. (1977) Glucoregulation during Moderate Exercise in Insulin Treated Diabetics. The Journal of Clinical Endocrinology \& Metabolism, 45, 641-652. http://dx.doi.org/10.1210/jcem-45-4-641

[15] Schneider, S.H., Vitug, A., Ananthakrishnan, R. and Khachadurian, A.K. (1991) Impaired Adrenergic Response to Prolonged Exercise in Type I Diabetes. Metabolism, 40, 1219-1225. http://dx.doi.org/10.1016/0026-0495(91)90219-M

[16] Galassetti, P., Tate, D., Neill, R., Morrey, S., Wasserman, D. and Davis, S. (2003) Effect of Antecedent Hypoglycemia on Counterregulatory Responses to Subsequent Euglycemic Exercise in Type 1 Diabetes. Diabetes, 52, 1761-1769. http://dx.doi.org/10.2337/diabetes.52.7.1761

[17] Sandoval, D., Aftab Guy, D., Richardson, A., Ertl, A. and Davis, S. (2004) Effects of Low and Moderate Antecedent Exercise on Counterregulatory Responses to Subsequent Hypoglycemia in Type 1 Diabetes. Diabetes, 53, 1798-1806. http://dx.doi.org/10.2337/diabetes.53.7.1798

[18] Koivisto, V. and Felig, P. (1978) Effects of Leg Exercise on Insulin Absorption in Diabetic Patients. New England Journal of Medicine, 298, 79-83. http://dx.doi.org/10.1056/NEJM197801122980205

[19] Berger, M., Berchtold, P., Cuppers, H.J., Drost, H., Kley, H.K., Müller, W.A., et al. (1977) Metabolic and Hormonal Effects of Muscular Exercise in Juvenile Type Diabetics. Diabetologia, 13, 355-365. http://dx.doi.org/10.1007/BF01223279

[20] Berger, M., Assal, J.P. and Jorgens, V. (1980) Physical Exercise in the Diabetic. The Importance of Understanding Endocrine and Metabolic Responses. Diabetes \& Metabolism, 6, 59-69.

[21] Purdon, C., Brousson, M., Nyveen, S.L., Miles, P.D., Halter, J.B., Vranic, M. and Marliss, E.B. (1993) The Role of Insulin and Catecholamines in the Glucoregolatory Response during Intense Exercise and Early Recovery in InsulinDependent Diabetic and Control Subjects. The Journal of Clinical Endocrinology \& Metabolism, 76, 566-573.

[22] Mitchell, T.H., Abraham, G., Shiffrin, A., Leiter, L.A. and Marliss, E.B. (1988) Hyperglycemia after Intense Exercise in IDDM Subjects during Continuous Subcutaneous Insulin Infusion. Diabetes Care, 11, 311-317. http://dx.doi.org/10.2337/diacare.11.4.311

[23] American Diabetes Association (2004) Physical Activity/Exercise and Diabetes. Diabetes Care, 27, S58-S62. http://dx.doi.org/10.2337/diacare.27.2007.S58

[24] Rasmussen, O.W., Lauszus, F.F. and Hermansen, K. (1994) Effects of Postprandial Exercise on Glycemic Response in IDDM Subjects: Studies at Constant Insulinemia. Diabetes Care, 17, 1203-1205. http://dx.doi.org/10.2337/diacare.17.10.1203

[25] Huttunen, N.P., Kaar, M.L., Knip, M., Mustonen, A., Puukka, R. and Akerblom, H.K. (1984) Physical Fitness of Children and Adolescents with Insulin-Dependent Diabetes Mellitus. Annals of Clinical Research, 16, 1-5.

[26] Ludvigsson, J. (1980) Physical Exercise in Relation to Degree of Metabolic Control in Juvenile Diabetics. Acta Paediatrica, 69, 45-48. http://dx.doi.org/10.1111/j.1651-2227.1980.tb15310.x

[27] Huttunen, N.P., Lankela, S.L., Knip, M., Lautala, P., Kaar, M.-L., Laasonen, K. and Puukka, R. (1989) Effect of Once-a-Week Training Program on Physical Fitness and Metabolic Control in Children with IDDM. Diabetes Care, 12, 737-740. http://dx.doi.org/10.2337/diacare.12.10.737

[28] Sackey, A.H. and Jefferson, I.G. (1996) Physical Activity and Glycemic Control in Children with Diabetes Mellitus. Diabetic Medicine, 13, 789-793. http://dx.doi.org/10.1002/(SICI)1096-9136(199609)13:9<789::AID-DIA184>3.0.CO;2-5

[29] Herbst, A., Bachran, R., Kapellen, T. and Holl, R.W. (2006) Effects of Regular Physical Activity on Glycemic Control in Children with Diabetes Mellitus Type 1. Archives of Pediatrics and Adolescent Medicine, 160, 573-577. http://dx.doi.org/10.1001/archpedi.160.6.573

[30] Dahl-Jorgensen, K., Meen, H.D., Hanssen, K.F. and Aagenaes, O. (1980) The Effect of Exercise on Diabetic Control and Hemoglobin A1 (HbA1) in Children. Acta Paediatrica, 69, 53-56. http://dx.doi.org/10.1111/j.1651-2227.1980.tb15313.x

[31] Stratton, R., Wilson, D.P., Endres, R.K. and Goldstein, D.E. (1987) Improved Glycemic Control after Supervised 8-wk Exercise Program in Insulin-Dependent Diabetic Adolescents. Diabetes Care, 10, 589-593. http://dx.doi.org/10.2337/diacare.10.5.589

[32] Campaigne, B.N., Gilliam, T.B., Spencer, M.L., Lampman, R.M. and Schork, M.A. (1984) Effects of a Physical Activity Program on Metabolic Control and Cardiovascular Fitness in Children with Insulin Dependent Diabetes Mellitus. 
Diabetes Care, 7, 57-62. http://dx.doi.org/10.2337/diacare.7.1.57

[33] Mauvais-Jarvis, F., Sobngwi, E., Porcher, R., Garnier, J.P., Vexiau, P., Duvallet, A. and Gautier, J.-F. (2003) Glucose Response to Intense Aerobic Exercise in Type 1 Diabetes: Maintenance of Near Euglycemia Despite a Drastic Decrease in Insulin Dose. Diabetes Care, 26, 1316-1317. http://dx.doi.org/10.2337/diacare.26.4.1316

[34] Mosher, P.E., Nash, M.S., Perry, A.C., LaPerriere, A.R. and Goldberg, R.B. (1998) Aerobic Circuit Exercise Training: Effect on Adolescents with Well-Controlled Insulin-Dependent Diabetes Mellitus. Archives of Physical Medicine and Rehabilitation, 79, 652-657. http://dx.doi.org/10.1016/S0003-9993(98)90039-9

[35] Larsson, Y., Persson, B., Sterky, G. and Thoren, C. (1964) Functional Adaptation to Vigorous Training and Exercise in Diabetic and Nondiabetic Adolescents. Journal of Applied Physiology, 19, 629-635.

[36] Landt, K.W., Campaigne, B.N., James, F.W. and Sperling, M.A. (1985) Effects of Exercise Training on Insulin Sensitivity in Adolescents with Type I Diabetes. Diabetes Care, 8, 461-465. http://dx.doi.org/10.2337/diacare.8.5.461

[37] Roberts, L., Jones, T.W. and Fournier, P.A. (2002) Exercise Training and Glycemic Control in Adolescents with Poorly Controlled Type 1 Diabetes Mellitus. Journal of Pediatric Endocrinology and Metabolism, 15, 621-627. http://dx.doi.org/10.1515/JPEM.2002.15.5.621

[38] Zinman, B., Zuniga, S. and Kelley, D. (1984) Comparison of the Acute and Long Term Effects of Exercise on Glucose Control in Type 1 Diabetes. Diabetes Care, 7, 515-519. http://dx.doi.org/10.2337/diacare.7.6.515

[39] Huttunen, J.K., Lanisimies, E., Voutilainen, E., Ehnholm, C., Hietanen, E., Penttilä, I., et al. (1979) Effect of Moderate Physical Exercise on Serum Lipoprotein. Circulation, 60, 1220-1229. http://dx.doi.org/10.1161/01.CIR.60.6.1220

[40] Idzior-Walus, B., Mattock, M.B., Solnica, B., Stevens, L., Fuller, J.H. and the EURODIAB IDDM Complications Study Group (2001) Factors Associated with Plasma Lipids and Lipoproteins in Type 1 Diabetes Mellitus: The EURODIAB IDDM Complications Study. Diabetic Medicine, 18, 786-796. http://dx.doi.org/10.1046/j.0742-3071.2001.00571.x

[41] Herbst, A., Kordonouri, O., Schwab, K.O., Schmidt, F., Holl, R.W., et al. (2007) Impact of Physical Activity on Cardiovascular Risk Factors in Children with Type 1 Diabetes. Diabetes Care, 30, 2098-2100. http://dx.doi.org/10.2337/dc06-2636

[42] Swerdlow, A.J. and Jones, M.E. (1996) Mortality during 25 Years of Follow of a Cohort with Diabetes. International Journal of Epidemiology, 25, 1250-1261. http://dx.doi.org/10.1093/ije/25.6.1250

[43] Wasserman, D.H. and Zinman, B. (1994) Exercise in Individuals with IDDM. Diabetes Care, 17, 924-937. http://dx.doi.org/10.2337/diacare.17.8.924

[44] Mogensen, C.E. and Vittinghus, E. (1975) Urinary Albumin Excretion during Exercise in Juvenile Diabetes. Scandinavian Journal of Clinical and Laboratory Investigation, 35, 295-300. http://dx.doi.org/10.3109/00365517509095743

[45] Viberti, G.C., Jarrett, R.J. and McCartney, K.H. (1978) Increased Glomerular Permeability to Albumin Induced by Exercise in Diabetic Subjects. Diabetologia, 14, 293-300. http://dx.doi.org/10.1007/BF01223019

[46] Hilsted, J., Galbo, H. and Christensen, N.J. (1979) Impaired Cardiovascular Responses to Graded Exercise in Diabetic Autonomic Neuropathy. Diabetes, 28, 313-319. http://dx.doi.org/10.2337/diab.28.4.313

[47] Kahn, J.K., Zola, B., Juni, J.E. and Vinik, A.I. (1986) Decreased Exercise Heart Rate and Blood Pressure Response in Diabetic Subjects with Cardiac Autonomic Neuropathy. Diabetes Care, 9, 389-394. http://dx.doi.org/10.2337/diacare.9.4.389

[48] Margonato, A.P., Gerundini, P., Vicedomini, G., Gilardi, M.C., Pozza, G. and Fazio, F. (1986) Abnormal Cardiovascular Response to Exercise in Young Asymptomatic Diabetic Patients with Retinopathy. American Heart Journal, 112, 554-560. http://dx.doi.org/10.1016/0002-8703(86)90521-1

[49] Colhoun, H.M., Francis, D.P., Rubens, M.B., Underwood, S.R. and Fuller, J.H. (2001) The Association of Heart-Rate Variability with Cardiovascular Risk Factors and Coronary Artery Calcification: A Study in Type 1 Diabetic Patients and the General Population. Diabetes Care, 24, 1108-1114. http://dx.doi.org/10.2337/diacare.24.6.1108

[50] Kriska, A.M., LaPorte, R.E., Patrick, S.L., Kuller, L.H. and Orchard, T.J. (1991) The Association of Physical Activity and Diabetic Complications in Individuals with Insulin-Dependent Diabetes Mellitus: The Epidemiology of Diabetes Complications Study_-VII. Journal of Clinical Epidemiology, 44, 1207-1214. http://dx.doi.org/10.1016/0895-4356(91)90153-Z

[51] Waden, J., Forsblom, C., Thorn, L.M., Sraheimo, M., Rosengård-Bärlund, M., Heikkilä, O., et al. (2008) Physical Activity and Diabetes Complications in Patients with Type 1 Diabetes. Diabetes Care, 31, 230-232. http://dx.doi.org/10.2337/dc07-1238 